Janusz Adam Frykowski

Tomaszów Lubelski

\title{
Dzieje parafii unickiej pw. Kuźmy i Damiana w Klątwach do 1875 roku
}

\section{THE HISTORY OF THE SAINTS COSMAS AND DAMIAN UNIATE PARISH IN KLATWY UNTIL 1875}

The history of the village of Klatwy, the seat of the Saints Cosmas and Damian Uniate parish, dates back to at least fifteenth century. In 1462, due to the incorporation of the Duchy of Belz into the Kingdom of Poland, the village of Klatwy became part of the Starosty of Tyszowce and as a royal village functioned until 1768 the first partition of Polish- Lithuanian Commonwealth, Klatwy was annexed by the Habsburg Empire, then it became part of the Duchy of Warsaw and following the joint resolutions of the Congress of Vienna it was given to Russia.

Originally, the village of Klatwy belonged to the Greek Orthodox Church and after the incorporation of Red Ruthenia into the Crown of the Kingdom of Poland come under the influence of the Latin Church, therefore, the inhabitants of that region were of dual rites, both Eastern Orthodox (then Uniate) as well as Latin Church.

Key words: parish, Orthodox church, endowment, paroch (parish priest), Uniates, utensilis.

\section{Wprowadzenie}

Dzisiejsze Klątwy to wieś położona w środkowej części gminy Tyszowce, nad rzeką Huczwą, w powiecie tomaszowskim w województwie 
lubelskim. Miejscowość ta ma bogatą historię, o czym świadczą ślady osadnictwa sięgające neolitu i odkryta niedawno osada rolników kultury lubelsko-wołyńskiej na terenie Kolonii Klątwy². Pierwsza historyczna wzmianka o tej miejscowości pochodzi z końca XV stulecia $^{2}$. W związku z powyższym można się spodziewać, że miejscowość ma starsze korzenie, sięgające może nawet początków XV wieku. W okresie staropolskim Klątwy położone były w ziemi bełskiej, która do 1462 roku tworzyła oddzielne księstwo podległe książętom z mazowieckiej linii Piastów. Po śmierci ostatniego z nich, Władysława II, ziemia bełska weszła w skład Korony jako odrębne województwo ${ }^{3}$. Po włączeniu księstwa bełskiego do Korony, Klątwy weszły w skład dóbr królewskich. Wieś ta, razem z Perespą, Mikulinem i Przewalem, tworzyła niegrodowe starostwo, którego siedzibą były miasto Tyszowce ${ }^{4}$. Od I rozbioru Polski do 1809 roku wieś leżała w granicach monarchii austriackiej, następnie w wyniku powiększenia Księstwa Warszawskiego znalazła się w jego granicach i funkcjonowała tam do końca wojen napoleońskich. Kolejna zmiana przynależności nastąpiła w 1815 roku, kiedy to Klątwy znalazły się na terytorium utworzonego na kongresie wiedeńskim Królestwa Polskiego, zależnego od Cesarstwa Rosyjskiego ${ }^{5}$.

Ze względu na to, że Klątwy położone były w województwie i w powiecie bełskim, ich ludność poddana była oddziaływaniu dwóch funkcjonujących obok siebie diecezji: prawosławnej eparchii chełmskiej ${ }^{6}$ (po 1596 roku unickiej) oraz chełmskiej diecezji katolickiej obrządku

1 J. Frykowski, E. i J. Niedźwiedź, Dzieje miejscowości gminy Tyszowce powiat tomaszowski, Tyszowce-Zamość 2008, s. 45.

Rex Andreae Czurylo de Sthoyenycze 1000 fl. hung. debit pro 24 iun. 1495 in praetorio castri Premisliensis reponere vel introductionem in oppidum Tyssowcze cum villis Mikulnycze e Klathwi dare se obliga. Zob.: Matricularum Regni Summaria, t. II, wyd. T. Wierzbowski, Warszawa 1905, s. 23.

$3 \quad$ Z. Gloger, Geografia historycznaziem dawnej Polski, Kraków 1903, s.226.Źródta dziejowe, t. XVIII, część I, Polska XVI wieku pod względem geograficzno-statystycznym, t. VII, część I, Ziemie Ruskie. Ruś Czerwona, oprac. A. Jabłonowski, Warszawa 1902, s. 20.

$4 \quad$ Szerzej na temat starostwa tyszowieckiego zob.: J. Frykowski, Niegrodowe starostwo tyszowieckie $w$ latach 1519-1768. Studium społeczno-gospodarcze, Tomaszów Lubelski 2009.

5 Więcej na temat historii tej wsi zob.: J. Frykowski, E. i J. Niedźwiedź, Dzieje..., op. cit., s. 36-37.

$6 \quad$ A. Poppe, Kościót i państwo na Rusi w XI wieku, Warszawa 1968, s. 178; A. Gil, Prawostawna eparchia chetmska do 1596 r., Lublin-Chełm, 1999, s. 61; L. Bieńkowski, Diecezja prawostawna, [w:] R. Łukaszyk, L. Bieńkowski, F. Gryglewicz (red.), Encyklopedia katolicka, Lublin 1988, t. III, kol. 132; J. Mazuryk, 
łacińskiego. Granice administracyjne obu diecezji niemal się pokrywały, więc zamieszkiwała ją na pewno ludność obydwu wyznań, a po 1596 roku - zarówno dwóch wyznań, jak i dwóch obrządków?

Artykuł ukazuje dzieje nieistniejącej już parafii unickiej pw. Kuźmy i Damiana w Klątwach od momentu pojawienia się informacji o niej w źródłach do 1875 roku, czyli do likwidacji unii na ziemiach Królestwa Kongresowego. Niestety, dzieje parafii w XVII wieku, w przeciwieństwie do XVIII i trzech ćwierci XIX stulecia, przedstawione są dość ogólnikowo ze względu na niedostateczną ilość materiałów źródłowych.

\section{Powstanie parafii}

Pierwsza informacja o świątyni prawosławnej w Klątwach, pochodzi z rejestru poborowego z 1540 roku, w którym widnieje opodatkowany pop z tej wsi ${ }^{8}$. Kolejny zapis potwierdzający funkcjonowanie parafii znajduje się w rejestrze poborowym z 1564 roku i dotyczy opodatkowania „synagogi” w Klątwach w wysokości 2 zł $^{9}$. Inny zapis (w lustracji starostwa tyszowieckiego z 1570) informuje, że pop z tej cerkwi uiszczał 1 zł czynszu rocznie ${ }^{10}$. Zdarzały się, jak to miało miejsce w 1573 roku, przerwy w funkcjonowaniu parafii, co zostało poświadczone wpisem: „Pop mortus est”"1. Jak pokazują późniejsze źródła podatkowe była to sytuacja wyjątkowa, gdyż w kolejnych źródłach podatkowych za lata 1574-1585 funkcjonowanie parafii jest potwierdzone opłacaniem przez parocha podatku w wysokości 2 zł rocznie ${ }^{12}$. Kolejne dane dokumentujące istnienie parafii pochodzą z początków XVII wieku. W lustracji starostwa tyszowieckiego z 1616 r. widnieje wpis, że pop

S. Panyszko, O. Ostapiuk, Badania archeologiczne latopisiwego Uhrowieska, „Archiwum Polski Środkowowschodniej”, nr 3 (1998), s. 175-182.

A. Gil, Prawosławna Eparchia Chetmska do 1596 r., Lublin 2005, s. 167; A. Mironowicz, Struktura organizacyjna Kościoła prawosławnego $w$ Polsce $w$ X-XVIII wieku, [w:] L. Adamczuk, A. Mironowicz (red.), Kościót prawostawny w Polsce dawniej i dziś, Warszawa 1993, s. 48-58; L. Bieńkowski, Diecezja prawosławna, kol. 132.

Archiwum Główne Akt Dawnych (dalej: AGAD), Archiwum Skarbu Koronnego (dalej: ASK), sygn. 37, k. 447. Ibidem, sygn. 51, k. 219.

Żereła do istoryi Ukrainy-Rusy, t. VII, oprac. M. Gruszewskij, Lviv 1900, s. 298. AGAD, ASK, sygn. 36, k. 308. 
Hryć z żoną zapłacił czynsz w wysokości 1 zł rocznie ${ }^{13}$. Kolejny, o dwa lata późniejszy zapis w rejestrze podymnego informuje, że pop był opodatkowany 2 zł rocznie ${ }^{14}$. Parafia w tej wsi wymieniona jest także w wykazie z lat 1619-1620. W lustracji starostwa tyszowieckiego z 1627 roku widnieje zapis, że pop płacił z cerkwi czynsz w wysokości 2 zł15. W dwa lata późniejszym rejestrze podymnego odnotowano, że pop z tej wsi zapłacił $1 \mathrm{zł}^{16}$. Następna informacja pochodzi z 1649 roku, czyli z czasów burzliwego okresu powstania Chmielnickiego. Jest to relacja mówiąca o zniszczeniu we wsi wielu budynków, z wyraźnym zaznaczeniem, że budynek cerkwi ocalał, ale bez popa ${ }^{17}$. Potwierdzenia funkcjonowania parafii znajdują się w rejestrach pogłównego z lat 1674 i $1677^{18}$. W pierwszym, pod wykazem płacących pogłówne w Klątwach podpisany jest ks. Hieronim Hodczyński, w drugim wzmiankowano nieokreślonego z imienia protopopa, który za żonę i parobków uiścił podatek 9 zł. Kolejne wzmianki o istnieniu parafii w tej wsi zawarte sa w wykazie dekanatów z lat 1683-1685 oraz w rejestrze cerkwi diecezji chełmskiej i bełskiej z 1696 roku. Podobnych danych dostarcza taryfa podatku dziesięciu poborów z 1715, w której zapisano, że protopop klątwowski za żonę i dwóch parobków opłacił podatek w wysokości $18 \mathrm{zt}^{19}$.

Wiadomo, że zmiana w strukturze tej parafii nastąpiła pod koniec XVIII wieku, kiedy to znaczna cześć diecezji chełmskiej znajdowała się pod zaborem austriackim. Wówczas to, w tzw. okresie józefińskim, miała miejsce likwidacja wielu mniejszych parafii i przekształcenie ich w cerkwie filialne ${ }^{20}$. Taki właśnie los spotkał niezbyt odległą od Klątw parafię w Mikulinie, która przez władze austriackie została zdegradowana do rangi cerkwi filialnej i włączona do parafii klątwowskieje1.

\footnotetext{
13 Ibidem, sygn. 47, k. 51.

14 Центральний Державний Історичний Архів України у Львові (dalej ЦДІАУЛ), фонд (dalej ф.) 2, on. 1, cnpaba (dalej c.) 203, s. 375; ф. 1, on. 1, c. 598, s. 1258. Archiwum Państwowe w Lublinie (dalej: APL), Księgi Grodzkie Grabowieckie (dalej: KGG), sygn. 122, k. 12.

16 ЦДІАУЛ, ф.1, on. 1, c. 598, s. 1258.

17 Ibidem, on. 1, c. 596, s. 35.

APL, KGG, sygn. 93, s. 1453-1485; sygn. 254, k. 747.

ЦДІАУЛ, ф. 2, on. 1, c. 218, s. 50.

W. Kołbuk, Duchowieństwo unickie w Królestwie Polskim 1835-1875, Lublin 1992, s. 15-17. W. Osadczy, Kościót i Cerkiew na wspólnej drodze. Concordia 1863. Z dziejów porozumienia między obrzadkiem greckokatolickim a łacińskim $w$ Galicji Wschodniej, Lublin 1999, s. 51.

В. Слободян, Церкви Холмскоі епархї, Львів 2005, s. 290.
} 
Parafia ta pod względem organizacyjnym podlegała najpierw protopopii, a później dekanatowi tyszowieckiemu i w jego strukturach funkcjonowała do 1866 roku, czyli do czasu likwidacji tej jednostki²2. Wówczas to władze rosyjskie, w celu dostosowania granic dekanatów do podziału administracyjnego, zredukowały liczbę dekanatów z 21 do 12 co spowodowało, że parafia w Klątwach znalazła się na obszarze działania dekanatu tomaszowskiego.

\section{Cerkiew parafialna}

Po raz pierwszy wygląd cerkwi pw. Kuźmy i Damiana w Klątwach znalazł się w protokole wizytacji z 15 października 1731 roku $^{23}$. Czynności kontrolnych dokonali wówczas komisarze: ks. Józef Ostaszewski i ks. Jan Jakielnicki. Z relacji wizytatorów wynika, że świątynia była budowlą drewnianą pokrytą gontem. Pośrodku dachu znajdowała się nieokreślonej wielkości kopuła zwieńczona żelaznym krzyżem. Do cerkwi prowadziło dwoje drzwi. Pierwsze z nich, wiodące do babińca, nie posiadały zawiasów (być może zamocowano je na skórzanych pasach) i były zamykane na zasuwę ${ }^{24}$. Drugie drzwi, prowadzące do cerkwi, także nie posiadały zawiasów, a zamykane były „zaszczepką na trzech ogniwach z probojem". Nad kruchtą znajdowała się dzwonnica z 3 dzwonami, 1 większym i 2 mniejszymi. Światła dziennego do cerkwi dostarczało 5 okien oprawionych w drewniane ramy. Wśród

22 A. Gil,Chetmska diecezja unicka 1596-1810.Dziejeiorganizacja. Studiai materiaty $z$ dziejów chrześcijaństwa wschodniego w Rzeczpospolitej, Lublin 2005, s. 306, 313; Idem, Chetmskie diecezje obrzadku wschodniego. Zagadnienia organizacji terytorialnej w XVII i XVIII wieku, [w:] S. Stępień (red.), Polska-Ukraina. 1000 lat sasiedztwa, t. 5, Przemyśl 2000, s. 43-44, 51.

APL, ChKGK, sygn. 100, k. 53v-54.

Znaczenie sakralizmów i innych pojęć występujących w artykule zob.: Z. Gloger, Encyklopedia staropolska, t. 2, Warszawa 1985; A. Jougan, Stownik kościelny łacińsko-polski, Sandomierz 2013; A. Markunas, T. Uczitiel, Popularny słownik sakaralizmów polskich i ukrainskich, Poznań 2001; O. Narbutt, Historia i typologia ksiag liturgicznych bizantyńsko-słowiańskich. Zagadnienie identyfikacji wedtug kryterium treściowego, Warszawa 1979; B. Pańczuk, Księgi liturgiczne, [w:] A. Szostek, E. Ziemann, R. Sawa, K. Góźdź, J. Herbut, S. Olczak, R. Popowski (red.), Encyklopedia katolicka, Lublin 2004, t. X, kol. 110; B. M. Seniuk, Osiemnastowieczna terminologia z zakresu architektury $i$ sztuki cerkiewnej oraz organizacji kościoła wschodniego. Materiaty do stownika na podstawie protokołów wizytacyjnych Eparchii Włodzimierskiej, [w:] S. Stępień (red.), Polska - Ukraina. 1000 lat sasiedztwa, t. 5, Przemyśl 2000, s. 309-346; E. Smykowska, Liturgia prawostawna. Maty stownik, Warszawa 2004; I. Turnau, Słownik ubiorów. Tkaniny, wyroby pozatkackie, skóry, brońiklejnoty orazbarwy znane $w$ Polsce od średniowiecza do poczatku XIX w., Warszawa 1999. 
nich 2 były umiejscowione na ołtarzu wielkim, a 1 niewielkie - w kopule. Przy cerkwi od strony drogi położony był cmentarz „ogrodzony albo oparkaniony dylami”. Wizytatorzy zapisali także, że w wyniku powodzi ,z tyłu [...] cerkwi poprzez podmycie wody nie tylko parkan oderwało, ale w połowie cmentarza trupy umarłych [woda] zabrała i podmywała". Jak pokazuje protokół wizytacji z 26 października 1760 roku szkody musiały być na tyle poważne, że zaistniała potrzeba wybudowania nowej cerkwi. Fakt taki potwierdził ks. Maksymilian Ryłło, biskup chełmski, zapisując $\mathrm{w}$ protokole wizytacji, że zastał na nowo wybudowaną świątynię ${ }^{25}$. Hierarcha zapisał dalej, że do jej wnętrza prowadziły drzwi osadzone na żelaznych zawiasach i zamykane na wewnętrzny zamek. Co prawda wizytator nie podał, ile świątynia miała okien, ale nadmienił, że były one drewniane i zabezpieczone „żelaznymi sztabami”. Zabezpieczenie okien związane było zapewne z kradzieżami, do których mogło tu dochodzić, podobnie jak w cerkwi $\mathrm{w}$ niedalekich Werechaniach ${ }^{26}$. W związku z budową świątyni została także wystawiona nowa dzwonnica z 3 dzwonami. O cmentarzu jest tylko informacja, że nie był on całkiem oparkaniony. Wygląd cerkwi i jej otoczenia opisano w protokole wizytacji z 23 marca 1775 roku $^{27}$. Dzięki temu źródłu wiadomo, że poza wcześniej wspomnianymi elementami świątynia ta miała 3 kopuły pokryte blachą. W dekrecie powizytacyjnym ks. Michał Grabowiecki, dziekan strzemilicki, nakazał parafianom i parochowi, żeby całkowicie oparkanili cmentarz i „dzwonnicę na mniejszą przerobili i pokryli”. Ostatni odnaleziony osiemnastowieczny opis cerkwi pochodzi z protokołu wizytacji odbytej 20 sierpnia 1780 roku przez ks. Juliana Szponringa ${ }^{28}$. Wizytator o świątyni napisał: „W ścianach dobra, potrzebuje zaopatrzenia w dachu, okien 4 oprawionych w drzewo zaopatrzonych w żelazne kraty, drzwi na zawiasach żelaznych z zamkiem wewnętrznym”. Wspomniał też o dzwonnicy z 3 dzwonami usytuowanej na cmentarzu zaznaczając, że „cmentarz [był] opadły po części”. W związku z tym w dekrecie powizytacyjnym nakazał pod karą parochowi „bez zwłoki przez dwie niedziele” cmentarz poprawić, natomiast parafianom dach na cerkwi poprawić.

$25 \quad$ APL, ChKGK, sygn. 110, s. 404.

26 Dziekan tomaszowski, ks. Jan Panasiński, w protokole wizytacji cerkwi werechańskiej zapisał: „Sprzęty cerkiewne ozdobne według inwentarza, które [paroch] nie w cerkwi, tylko w domu utrzymuje, bo ta cerkiew w lesie za wsią na górze ustawicznie jest przez złodziei rozbijana, i wiele już sprzętu pokradziono". Zob. ibidem, sygn. 139, k. 282. 
Kolejne dane dotyczące cerkwi parafialnej w Klątwach i filialnej w Mikulinie pochodzą dopiero z trzeciej dekady XIX wieku. Niestety, informacje te ograniczają się jedynie do określenia stanu technicznego budowli i wymienienia elementów, które należało wyremontować. W wykazach kościołów wymagających „rychłej naprawy” za lata 1826-1835 wymieniono tylko świątynię parafialną w Klątwach (należy zatem sądzić, że cerkiew filialna w Mikulinie była w niezłym stanie technicznym $)^{29}$. Według tych wykazów w cerkwi klątwowskiej należało Historia naprawić dach, podwaliny i podłogę. Remonty te zostały wykonane między 1835 a 1836 rokiem, ponieważ wykazy o stanie cerkwi za lata 1837 i 1838 nie wymieniają cerkwi w Klątwach. Stan taki nie przetrwał długo, ponieważ w podobnych wykazach z lat 1840 i 1841 ponownie pojawiły sie zapisy przedstawiające stan cerkwi jako zły, co zostało potwierdzone protokołem narady nadzoru cerkiewnego z 13 marca 1841 $\mathrm{roku}^{30}$. Zgodnie z tym dokumentem, cerkwie w Klątwach i Mikulinie wymagały podważenia, podmurowania, nowej podłogi, naprawy dachu i nieokreślonej „znacznej reperacji”. Wiadomo także, że te świątynie zostały wyremontowane przed końcem 1841 roku. Kolejnych danych o stanie świątyń, a przy okazji o czasie ich powstania, dostarczaja podobne wykazy za lata $1849-1859^{31}$. Dzięki nim wiadomo, że cerkiew w Klątwach została wybudowana w 1754, a w Mikulinie w 1762 roku, a ponadto, że podczas oględzin pod koniec 1849 roku obydwie świątynie wymagały pokrycia dachów nowym gontem. Prace te zostały wykonane przed końcem 1852 roku, ponieważ wykaz o stanie cerkwi na koniec tego roku przedstawił przedmiotowe świątynie jako budowle w dobrym stanie technicznym, który to stan utrzymał się co najmniej do końca 1859 roku. Ostatnie dane o stanie technicznym oraz o istnieniu ikonostasów pochodzą ze spisów statystycznych z lat 1868 i $1872^{32}$. $\mathrm{W}$ pierwszym $\mathrm{z}$ wymienionych spisów jest informacja, że cerkiew w Klątwach jest świątynią nową, wybudowaną w 1867 r. Natomiast cerkiew filialna w Mikulinie znajdowała się w złym stanie, co nie może wydawać się niczym dziwnym ze względu na fakt, że miała ponad 100 lat (wystawiona była w 1754) i w związku z tym dokonujący spisu postulował jak najszybszy gruntowny remont. W źródle znajduje się ponadto informacja, że cerkiew parafialna wyposażona była zarówno

$29 \quad$ Ibidem sygn. 148 , s. 43, 81, 128; sygn. 149, s. 42, 107, 224, 300; sygn. 150, s. 152, $243,344$.

$30 \quad$ Ibidem, sygn. 151, s. 288, 331-332, 461, 537.

31 Ibidem, sygn. 154, s. 461, 670; sygn. 156, k. 43, 648; sygn. 157, k. 211; sygn. 158, k. 120; sygn. 159, k. 87; sygn. 161, k. 181. 
w ikonostas, jak i w carskie wrota. Takie same informacje o przedmiotowych świątyniach zawiera drugi spis z 1872 roku.

Wyznacznikiem kondycji i zamożności kościoła, oprócz okazałości bryły świątyni i jej uposażenia, jest także jego zasobność w utensylia. Danych o naczyniach liturgicznych w cerkwi klątwowskiej dostarczają protokóły wizytacji z lat 1732, 1760, 1775 i 1780 ${ }^{33}$. Należy zaznaczyć, że w badanym okresie zarówno liczba naczyń liturgicznych jak i jakość ich wykonania zmieniały się. Jak pokazują źródła, świątynia była dość dobrze zaopatrzona w te utensylia. Na wyposażeniu były puszki pro conservando Venerabili, kielichy, pateny, gwiazdy, łyżeczki, ampułki, miernice, vascula pro oleis sacris. Osobną grupę utensyliów stanowiły tekstylne podstawki i przykrycia stanowiące tzw. szaty kielicha, z których wymienione były wozduchy, velum oraz korporały.

Pierwsza informacja o ołtarzu (w badanym okresie ich liczba wahała się od 1 do 5) i jego wyposażeniu znajduje się w protokole wizytacji z 1731 roku $^{34}$. W źródle tym jest już widoczny wpływ latynizacji na cerkiew w Klątwach ${ }^{35}$. Wyrazem tego było „stolarskiej roboty, niemalowane" cyborium, umieszczone na Ołtarzu Wielkim, 2 dzwonki do mszy i 3 choragwie do procesji. Ołtarz od wiernych oddzielały carskie wrota. Po ich lewej stronie umieszczony był deesis oraz 3 ikony, tj. Najświętszej Maryi Panny, św. Piotra i św. Praksedy. Nad carskimi wotami znajdowały się kolejne 3 obrazy malowane na płótnie, a 2 ostatnie wymienione obrazy przedstawiały wizerunki Spasytiela oraz Kuźmy i Damiana. Wśród pozostałych utensyliów wymienione są krzyże zarówno drewniane jak i metalowe, trybularze, korony, dzwonki do mszy, antepedia, antyminsy, tabliczki, sznury korali, choragwie, obrusy, firanki i zasłonki. W badanym okresie liczba ołtarzy była zmienna i wahała się od 1 do $5^{36}$.

Szaty liturgiczne, zwane także aparatami lub paramentami, to rodzaj odzieży stosowanej w czasie liturgii, mającej na celu określenie funkcji osoby ją noszącej. O szatach liturgicznych w cerkwi klątwowskiej informuja protokoły wizytacji z lat 1731-1780 ${ }^{37}$. Wymienione tam są aparaty, alby, humerały, patrachele, narękwia i stuły. Podobnie jak

Ibidem, sygn. 100, k. 53v; sygn. 110, s. 404, sygn. 122, k. 252v-253; sygn. 127, k. 181-181v.

Ibidem, sygn. 100, k. 53v-54.

Szerzej na temat latynizacji w Kościele unickim zob.: D. Ciołko, Latynizacja Kościoła unickiego w Rzeczypospolitej po synodzie zamojskim, Białystok 2014.

APL, ChKGK, sygn. 110, s. 404; sygn. 122, k. 252v-253; sygn. 127, k. 181.

Ibidem, sygn. 100, k. 54; sygn. 110, s. 404; sygn. 122, k. 252v-253; sygn. 127, k. 181. 
w przypadku wyżej wymienionych utensyliów tak i wśród paramentów zmieniała się ich liczba, jak i materiał, z którego były wykonane.

Niezbędnym elementem wyposażenia każdej świątyni, oprócz argentariów i szat liturgicznych, były także księgi liturgiczne, według których w Kościele odprawia się nabożeństwa oraz udziela sakramentów. Dla parafii w Klątwach w badanym czasie ustalono 4 wykazy ksiąg pochodzące $\mathrm{z}$ lat $1731-1780^{38}$. W księgozbiorze $\mathrm{z}$ tego okresu wymienione są: Ewangelia, służebnik, trefołoj, szestodniewiec, triod cwietHistoria naja i postnaja, apostoł, psałterz, trebnik, irmołoj, czasosłów, minera, kazusy, mszał, oktoich, klucz do kazań i kazania ruskie. Wśród ksiąg szczególnie wyróżniała się bogato zdobiona Ewangelia, wydrukowana w formacie arkusza. Oprawiona była „pod złoty i srebrny merynos”, a całość zamykana mosiężnymi klauzurkami. Na przedniej okładzinie znajdowała się ,,srebrna sztuczka” i wizerunek Zwiastowania Najświętszej Maryi Panny, a na rogach 4 mosiężne narożniki. Na środku tylnej okładziny znajdowała się mosiężna tabliczka i 4 mosiężne „pukle”. W przypadku służebnika wiadomo, że był de novo oprawiony i wydany we Lwowie w formacie in quarto. Apostoł był wydrukowany w formacie arkusza i miał nieokreśloną biała oprawę. O szestodniewcu i trefołoju wiadomo, że były drukowane, pierwszy w formacie połowy arkusza, drugi zaś arkusza i stan tego ostatniego był określony jako „dobry”. $\mathrm{O}$ pozostałych księgach posiadamy jeszcze mniej informacji. W przypadku czasosłowu, psałterza, kazusów, dwóch triodów i minei podano tylko, że były drukowane, a pozostałe księgi były napisane ręcznie. W powyższym księgozbiorze wśród ksiąg występowała dość duża rotacja, co nie było zjawiskiem odosobnionym. Podobnie działo się także $\mathrm{w}$ innych cerkwiach dekanatu tyszowieckiego i tomaszowskiego ${ }^{39}$.

\section{Uposażenie duchowieństwa}

Pierwszych danych o beneficjum cerkiewnym dostarcza protokó wizytacji z 1731 roku $^{40}$. Według niego paroch miał do swojej dyspozycji grunt orny, którego wielkość określono miarą 6 korcy wysianego ziarna, ogród, na którym można było wysiać pół ćwierci miary

$38 \quad$ Ibidem, sygn. 100, k. 54; sygn. 110, s. 404; sygn. 122, k. 253.

39 Zob.: J. A. Frykowski, Dzieje parafii unickiej w Pienianach, „Radzyński Rocznik Humanistyczny", nr 12 (2014), s. 23-49; Idem, Z dziejów Diecezji Unickiej w Chetmie. Parafia unicka w Easzczowie do 1863 r., „Rocznik Chełmski”, t. 17 (2013), s. 53-69; Idem, Parafie prawostawne $i$ unickie $w$ Tyszowcach XVI-XVIII wieku, „Radzyński Rocznik Humanistyczny”, nr 10 (2012), s. 33-49; Idem, Parafia unicka w Rachaniach do 1811 roku, „Annales UMCS”, vol. LXVII, nr 2 (2012), s. 7-24.

APL, ChKGK, sygn. 100, k. 54. 
Historia Kościoła

tyszowieckiej ziarna, drugi niewielki ogród o nieokreślonej wielkości (w źródle nazwany „ogródek”) i łąkę, której wielkość określono na 10 kosiarzy $^{41}$. Ponadto paroch pobierał skopszczyznę (dziesięcinę) w wymiarze jednej kopy z półłanka i pół kopy z ćwierci gruntu. W źródle zawarta jest jeszcze adnotacja, że do parafii należał też ogród za stodołą i gaik, ale został zabrany i przyłączony do dworu. Niewiele informacji o uposażeniu parocha przynosi protokół wizytacji z 1761 $\mathrm{roku}^{42}$. W kwestii gruntów jest tylko niewiele mówiący zapis: „pola, łąki według dawnych wizytacji”. Zdecydowanie więcej miejsca biskup M. Ryłło poświęcił sprawie dziesięciny. Pierwszy zapis mówi, że była ona pobierana w wysokości kopy z półłanka gruntu parafianina. Zdecydowanie ciekawsze są zapisy w dekrecie powizytacyjnym. Pierwsza brzmi: „Ponieważ paroch ważył się bez powiadomienia zwierzchności kościelnej z sołtysami klątwowieckimi kompozycje czynić o dziesięcinę ze szkodą cerkwi. Przeto biskup nakazuje Piotrowi [Łuszczyńskiemu] tę dziesięcinę odebrać aż do dnia dzisiejszego”, zaś druga: „Jako że przez parocha $z$ tej wsi dziesięcina snopowa upadła, nakazuję aby dziesięcina według dawnego zwyczaju i regestrów oddawana była, tak jak w całym starostwie tyszowieckim". Z powyższych zapisów wyraźnie wynika, że za wszystkie problemy związane z egzekwowaniem dziesięciny hierarcha obwiniał ks. Grzegorza Łuszczyńskiego, a uregulowanie tej sytuacji nakazał synowi parocha, wikaremu Piotrowi. Zapewne proboszcz nie uiszczał pogłównego, skoro w tym samym dekrecie biskup nakazał, żeby podatek był płacony. Dużo ciekawych informacji, zwłaszcza o położeniu gruntów cerkiewnych dostarcza protokół wizytacji z 1775 roku $^{43}$. Według niego grunty orne położone były w dwóch miejscach. Pierwsze pole wielkości półłanka z jednej strony graniczyło z łanem sołtysim, a z drugiej z gruntem Jana Łacha. Drugi kawałek wielkości ćwierci z jednej strony przez miedzę graniczył z polem arendarskim, z drugiej zaś z łąkami, które ciągnęły się od granicy wsi Czartowiec. Między tymi łąkami położona był łąka

41 Znaczenie pojęć gospodarczych zob.: J. Dudziak, Dziesięcina, [w:] R. Łukaszyk, L. Bieńkowski, E. Gryglewicz (red.), Encyklopedia katolicka, t. 4, Lublin 1985, kol. 600-601; I. Ihnatowicz, Vademecum do badań nad historia XIX i XX wieku, cz. 1, Warszawa 1967; M. Kamler, Folwark, [w:] A. Mączak (red.), Encyklopedia historii gospodarczej Polski do roku 1945, Warszawa 1981, s. 173-176; S. Russocki, Podymne, [w:] A. Mączak (red.), Encyklopedia historii gospodarczej Polski do 1945 r., t. 2, Warszawa 1981, s. 94; J. Szymański, Nauki pomocnicze historii, Warszawa 2005; A. Zajda, Nazwy staropolskich powinności feudalnych, danin i optat (do 1600 r.), Warszawa - Kraków 1979.

APL, ChKGK, sygn. 110, s. 404. 
cerkiewna wielkości na 6 kosiarzy. Druga łąka wielkości na 12 kosiarzy ciągnęła się od nieokreślonej ,,poprzecznej drogi” do granicy gruntów wsi Czartowiec. Kolejne dane dotyczące łąk prezentują się następująco: na „Krasnym” miała wielkość na 2 kosiarzy, na „Kolibach” na 1 kosiarza, na „Sobolu” na 2 kosiarzy i pod gaikiem także na 2 kosiarzy. Ponadto był tam ogród, na którym stała plebania. Wymiar dziesięciny nie uległ zmianie. Ostatnich osiemnastowiecznych danych w tym zakresie dostarcza protokół wizytacji z 1780 roku $^{44}$. Poza potwierdzeniem Historia informacji podanych 5 lat wcześniej, stwierdza występowanie drugiego ogrodu, który został nabyty między tymi dwoma wizytacjami.

Tabela nr 1. Wielkość użytków rolnych i dziesięciny w parafii Klątwy w latach 1814-1870.

\begin{tabular}{|c|c|c|c|c|c|}
\hline Data & Wieś & Grunty orne & Ląki & Ogrody & Dziesięcina \\
\hline \multirow{2}{*}{1814} & Klątwy & 44 morgi & 12 mórg & $\begin{array}{l}1 \frac{1 / 2}{2} \\
\text { morgi }\end{array}$ & $7 \mathrm{kop}$ \\
\hline & Mikulin & 26 mórg & 31 mórg & $\begin{array}{l}11 / 2 \\
\text { morgi }\end{array}$ & $6 \mathrm{kop}$ \\
\hline \multicolumn{2}{|c|}{ Razem } & \multicolumn{3}{|c|}{116 mórg } & 13 kop \\
\hline \multirow{2}{*}{1815} & Klatwy & \multicolumn{3}{|c|}{50 mórg 100 sążni } & 7 kop 2 snopy \\
\hline & Mikulin & \multicolumn{3}{|l|}{40 mórg 80 sążni } & 6 kop 24 snop \\
\hline \multicolumn{2}{|c|}{ Razem } & \multicolumn{3}{|l|}{90 mórg 180 sążni } & 13 kop 26 snopów \\
\hline \multirow{2}{*}{1816} & Klątwy & \multicolumn{3}{|l|}{57 mórg 800 sążni } & $7 \mathrm{kop}$ \\
\hline & Mikulin & \multicolumn{3}{|l|}{58 mórg 800 sążni } & 6 kop \\
\hline \multicolumn{2}{|c|}{ Razem } & \multicolumn{3}{|c|}{116 mórg } & $13 \mathrm{kop}$ \\
\hline \multirow{2}{*}{1824} & Klątwy & $\begin{array}{l}70 \text { mórg } 1136 \\
\text { sążni }\end{array}$ & \multicolumn{2}{|c|}{21 mórg 1060 sążni } & 7 kop 45 snopów \\
\hline & Mikulin & 64 mórg 173 sążni & \multicolumn{2}{|c|}{17 mórg 231 sążni } & 7 kop 30 snopów \\
\hline \multicolumn{2}{|c|}{ Razem } & \multicolumn{3}{|c|}{173 morgi 100 sążni } & 15 kop 15 snopów \\
\hline \multirow{2}{*}{1840} & Klątwy & \multirow[b]{2}{*}{36 mórg 366 sążni } & \multirow{2}{*}{$\begin{array}{l}64 \text { mórg } \\
173 \text { sążni }\end{array}$} & \multirow{2}{*}{$\begin{array}{l}1 \text { mórg } \\
800 \\
\text { sążni }\end{array}$} & 30 snopów od \\
\hline & Mikulin & & & & $\begin{array}{l}\text { cwiertnika, } 15 \text { od } \\
\text { zagrodnika }\end{array}$ \\
\hline \multicolumn{2}{|c|}{ Razem } & \multicolumn{3}{|c|}{101 mórg 1339 sążni } & - \\
\hline \multirow[t]{2}{*}{1870} & Klątwy & 41 1/4 morgi & 10 mórg & $\begin{array}{l}10^{1 / 4} \\
\text { morgi } \\
\text { (las) }\end{array}$ & - \\
\hline & Mikulin & 71 1/2 morgi & 14 mórg & - & - \\
\hline \multicolumn{2}{|c|}{ Razem } & \multicolumn{3}{|c|}{147 mórg } & - \\
\hline
\end{tabular}

Źródła: APL, ChKGK, sygn. 151, s. 374; sygn. 167, k. 85-85v.; sygn. 230, k. 5v, 8v-9v; sygn. 602 , k. $74 \mathrm{v}-75$; sygn. 604 , s. $70-71$.

44 Ibidem, sygn. 127, k. 181v. 
Analiza powyższej tabeli pokazuje, że powierzchnia gruntów wchodzących w skład gospodarstwa parocha w Klątwach była zmienna w czasie. Można być pewnym, że na powiększenie wielkości gruntów mieli wpływ hojni kolatorzy i wierni, trudniej jest ustalić, czym powodowany był ubytek w areale. Można domniemywać, że na zmniejszenie wielkości gruntu w latach 1824-1840 miało wpływ zaangażowanie parocha w powstaniu listopadowym, czego konsekwencją mogła być konfiskata części gruntów przez władze rosyjskie. Mogło także dojść do regulacji gruntów, dzięki której paroch otrzymał te jakościowo lepsze, ale za to o mniejszej powierzchni. Przyczyna mogła być także bardziej prozaiczna, być może paroch po prostu z nieznanych powodów sprzedał cześć gruntów.

Tabela 2. Dochody parochów klątwowskich w latach 1814-1870.

\begin{tabular}{|c|c|c|c|c|c|c|c|c|c|}
\hline \multirow{2}{*}{ Dochody z: } & \multicolumn{9}{|c|}{ W latach (wyrażone w złotych): } \\
\hline & 1814 & 1815 & 1816 & 1817 & 1818 & 1819 & 1920 & 1826 & 1832 \\
\hline gruntów & \multirow{2}{*}{300} & 281 & 232 & 281 & 281 & \multirow{2}{*}{500} & \multirow{2}{*}{493,12} & \multirow{2}{*}{495,12} & \multirow{2}{*}{493,12} \\
\hline dziesięcin & & 52 & 52 & 52 & 52 & & & & \\
\hline kompetencje $^{45}$ & - & - & - & - & - & 46 & - & - & - \\
\hline Razem & 300 & 333 & 334 & 333 & 333 & 546 & 493,12 & 495,12 & 493,12 \\
\hline \multirow{2}{*}{ Dochody z: } & \multicolumn{9}{|c|}{ W latach (wyrażone w srebrnych rublach): } \\
\hline & 1844 & 1845 & 1854 & 1855 & 1856 & 1857 & 1870 & & \\
\hline gruntów & 74,01 & 74,01 & 74,01 & 74,01 & 74,01 & 74,01 & - & & \\
\hline wynagrodzenie & - & - & - & - & - & - & 300 & & \\
\hline Razem & 74,01 & 74,01 & 74,01 & 74,01 & 74,01 & 74,01 & 300 & & \\
\hline
\end{tabular}

Źródła: APL, ChKGK, sygn. 148, s. 36; sygn. 149, 230; sygn. 152, s. 32-33; sygn. 155 ,

k. 222 ; sygn. 156 , k. 471 ; sygn. 167 , k. $85-85 \mathrm{v}$; sygn. 230 , k. $24 \mathrm{v}-25$; sygn. 602 , k. $74 \mathrm{v}-75,152$; sygn. 604 , s. $70-71$.

Analiza powyższej tabeli pozwoli jedynie na prześledzenie kształtowania się dochodu parocha w badanych latach. Pokaże ona jak w tym zakresie, w poszczególnych latach, wyglądał profit duchownego, czy ulegał zwiększeniu, czy też zmniejszeniu. Dopiero zestawienie tych wartości z dochodami parochów w innych parafiach pozwoli na określenie zamożności duchownego w Klątwach na tle innych kapłanów. I tak, wśród plebanów dekanatu tyszowieckiego w 1819 r., najniższy dochód w wysokości 345 zł 6 gr. osiągnął paroch z Łaszczowa,

$45 \quad$ Fundusze na kompetencje pochodziły z zajętych przez państwo dóbr kościelnych i przeznaczone były na cele kultu. Zob.: E. M. Ziółek, Między tronem a ołtarzem. Kościót i państwo w Księstwie Warszawskim, Lublin 2012, s. 22, 25. 
a najwyższy - 1036 zł 29 gr. 10 denarów z Tyszowiec. W 1832 roku najniższy dochód osiągnął paroch z Żernik - 280 zł 14 gr., zaś najwyższy - 688 zł 15 gr. z Poturzyna. W 1857 roku najniższy dochód, tj. 42 rb. 13 kop. miał paroch w Łaszczowie, a najwyższy czyli $103 \mathrm{rb} .36$ 1/2 kop. duchowny z Poturzyna ${ }^{46}$. Już na podstawie tych danych widać, że paroch klątwowski pod względem dochodu nie odbiegał od średniej dochodu dla tego dekanatu.

Nie bez znaczenia dla utrzymania duchownych było pobierana przez Kościoła nich iura stolae ${ }^{47}$. O wysokości tej opłaty uzyskanej przez proboszcza w Klątwach informują źródła z lat 1817, 1818 i 1819, kiedy wyniosła ona kolejno 50, 30 i 46 zł ${ }^{48}$. Dla porównania, w pobliskim miasteczku (Tyszowcach) były to kwoty 106, 84 i 62 zł $^{49}$, w Łosińcu - 86, 90 i 60 zł rocznie $^{50}$, w Pienianach - 74, 56 i 47 zł $^{51}$, w Grodysławicach - 90, 81

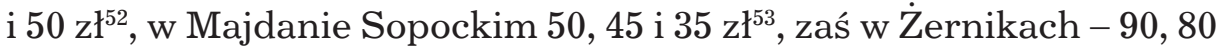
i $40 \mathrm{zt}^{54}$. Jak pokazują uprzednie dane, w porównaniu z powyższymi parafiami dochód parochów klątwowskich z tego tytułu należał do najniższych.

Dochody duchowieństwa były obciążone różnego rodzaju podatkami i opłatami na rzecz państwa, biskupa, urzędników diecezjalnych, dziekanów i właścicieli dóbr. Pierwsze XIX-wieczne dane o opodatkowaniu duchownego z Klątw pochodzą z 1815 roku $^{55}$. Paroch zapłacił wówczas podatek od 5 dymów w wysokości 49 zł 8 gr oraz uiścił liwerunek

46 Dochody parochów w dekanacie tyszowieckim w 1819 roku zob.: APL, ChKGK, sygn. 230, k. 23v-27' sygn. 149, s. 230-239; sygn. 156, k. 444-568.

47 Prawo do pobierania opłat iura stolae wynikało ze spełniania przez duchownych określonych posług religijnych, jak: chrzest, zapowiedzi, ślub, pogrzeb i błogosławieństwa kobiety po ślubie i chrzcie dziecka, tzw. wywody. Zob.: M. Karbownik, Ofiary iura stolae na ziemiach polskich w latach 1285-1918, Lublin 1995; Idem, Opodatkowanie duchowieństwai dóbrkościelnych naziemiach polskich wokresie zaborów 1772-1918, Lublin 1998, s. 49-52. W 1818 roku Komisja Rządowa Wyznań Religijnych i Oświecenia Publicznego wydała taksy wysokości opłat iura stolae. Ich wysokość była zależna od jednej z trzech klas, na jakie zostali podzieleni parafianie. Przynależność do klas zależała od majętności wiernego. Zob.: APL, ChKGK, sygn. 604, s. 438-439

APL, ChKGK, sygn. 230, k. 24v-25.

Ibidem, sygn. 230, k. 25v-26.

Ibidem, sygn. 228, k. 11v-12.

Ibidem, sygn. 230, k. 27v-28.

Ibidem, sygn. 230, k. 23v-24.

Ibidem, sygn. 228, k. 10-10v.

Ibidem, sygn. 230, k. 23v-24.

Ibidem, sygn. 230, k. 1-1v. 
w zbożu w wysokości 5 garnców pszenicy, 3 korców 281/4 garnca żyta, 5 korców 16 garnców owsa i 8 cetnarów siana ${ }^{56}$. Dla porównania, w badanym roku w dekanacie tyszowieckim podatek podymny był płacony od 1 do 5 dymów w kwocie od 5 do 50 zł. Natomiast w przypadku liwerunku miało to wielkości od 11/2 do 14 garnców pszenicy, od 29 garnców do 5 korców żyta, od 2 korców 15 garnców do 8 korców 25\%3 garnca owsa, od 16 funtów do 17 cetnarów siana i od 1 do 6 cetnarów słomy ${ }^{57}$. W 1819 roku paroch klątwowski zapłacił 20 zł podymnego i 153 zł 10 gr liwerunku. W wykazie tym jest adnotacja: ,Tu ledwie nie wszystkie łąki w wodzie niezalewane, a bez względu liwerunek i podymne płaci”. Dla porównania w tym samym roku minimalne podymne w dekanacie tyszowieckim było płacone od 1 dymu w wysokości 8 zł 15 gr, maksymalnie od 4 dymów w wysokości 27 zł 17 gr. W tym roku liwerunek także był płacony w gotówce. Najmniej, bo 42 zł 17 gr zapłacił paroch z Posadowa, najwięcej 186 zł 29 gr duchowny z Tyszowiec ${ }^{58}$. Ostatnia informacja dotycząca opłaconych przez parocha w Klątwach podatków pochodzi z 1829 roku. Wówczas to pleban uiścił 17 zł podymnego i 102 zł 4 gr liwerunku. Natomiast w pozostałych parafiach podymne wahało się od 7 zł (Nabróż) do 34 zł (Tyszowce), natomiast liwerunek od 34 zł 22 gr (Łaszczów) do 120 zł 5 gr (Tyszowce) ${ }^{59}$.

\section{Plebania i zabudowania gospodarcze}

Pierwsze informacje o plebanii w Klątwach pochodzą z 1731 roku $^{60}$. Dokonujący wówczas przeglądu parafii wizytator w protokole zapisał, że proboszczówka była budynkiem drewnianym i że składała się z izby, piekarni i alkierza. Z budynków gospodarczych wymieniony jest folwark i stara stodoła. W związku z tym, że w okresie staropolskim mianem folwarku określano gospodarstwo rolne lub rolno-hodowlane, musiały w nim być budynki gospodarcze. Wobec powyższego, można być pewnym, że pleban posiadał pomieszczenia dla zwierząt typu: stajnia, wołownia, chlew lub pomieszczenia na paszę, takie jak

$56 \quad$ Dla przykładu w pobliskim Nabrożu, paroch zapłacił podymne od 2 dymów 15 zł 15 gr, a liwerunku 1¹/2 garnca pszenicy, 1 korzec 26 garnców żyta, 4 korce 12 $3 / 4$ garnca owsa oraz po 2 cetnary siana. Zob. ibidem, sygn. 230, k. 1-1v.

Dokładne dane dla poszczególnych parafii dekanatu tyszowieckiego zob.ibidem, sygn. 230, k. 1-1v.

Wysokości podatków w parafiach dekanatu tyszowieckiego w 1819 r. zob. ibidem, sygn. 230, k. 17v-18.

Wysokości podatków w parafiach dekanatu tyszowieckiego w 1829 r. zob. ibidem, sygn. 148, s. 187-189. 
spichlerz, stodoła czy szopa. Oprócz folwarku oddzielnie wymieniona była szopa - zapewne ze względu na to, że była budynkiem starym, na co prawdopodobnie chciał zwrócić uwagę wizytator. Zarówno plebania jak i pozostałe budynki musiały być w nie najlepszym stanie technicznym, skoro wizytujący zapisał: ,podmycie wody nie tylko parkan oderwało, ale [...] też tam i połowę plebanii z budynkami zniosło". Kolejne dane w tym zakresie, są o ponad czterdzieści lat późniejsze i pochodzą z $1775 \mathrm{roku}^{61}$. Zapis w protokole powizy tacyjnym brzmi: ,plebania stoi drewniana ale wielkiej reperacji potrzebująca. Gumno chruściane stare po części zdezelowane", źródło jednoznacznie określa, że stan zabudowań był zły. Jak pokazały późniejsze dokumenty, stan proboszczówki był na tyle zły, że rozpoczęto budowę nowej, o której wizytujący parafię w 1780 roku napisał: „Ogród, na którym stoi nowo wybudowana niedokończona plebania. Ogród drugi, za drogą, na którym gumno chruściane plebańskie stoi”. Kolejne informacje o proboszczówce i zabudowaniach gospodarskich zarówno w siedzibie parafii, Klątwach, jak i przy cerkwi filialnej w Mikulinie pochodzą z początków XIX wieku. W zapisie źródłowym z 24 marca 1814 roku pojawia się wzmianka, że w Klątwach plebania jest w miernym stanie, natomiast „,budynki ekonomiczne ze wszystkim upadają". Jeszcze gorzej było w Mikulinie, gdzie zapis brzmi „Plebania niezdatna do zamieszkania, zdezelowana, budynki ekonomiczne ze wszystkim upadły"62. W kolejnych latach, jak wynika ze Stanu plebanii na dzień 31 października 1841 r., sytuacja się jeszcze pogorszyła. W przypadku siedziby parafii zapisano: „Plebania bardzo szczupła, zupełnie zdezelowana. Stodółka i obora zupełnie zdezelowane”, natomiast w przypadku Mikulina: „Domek szczupły, już upada, nie do użytku. Zabudowań gospodarskich nie ma" ${ }^{63}$. Kolejnych danych w tym zakresie dostarcza Wykaz statystyczny za $1846 r^{64}{ }^{64}$ Źódło to dostarcza wiele ciekawych informacji: wymienia i charakteryzuje budynki na dzień spisu oraz wymienia brakujące (według dokonującego spisu), które wcześniej być może istniały. I tak: w przypadku budynków mieszkalnych w Klątwach czytamy, że jeden jest w dobrym stanie, a drugiego brakuje (być może dla diaka). W Mikulinie natomiast jeden budynek potrzebował remontu. W przypadku parafialnych zabudowań gospodarczych podano, że jedno było w dobrym stanie, dwa następne potrzebowały remontu, a dwóch brakowało i trzeba je było wybudować. W Mikulinie natomiast jedno należało wyremontować

\footnotetext{
$61 \quad$ Ibidem, sygn. 122, k. 253.

62 Ibidem, sygn. 602 , s. $74 \mathrm{v}-75$.

$63 \quad$ Ibidem, sygn. 151, s. 417.

64 Ibidem, sygn. 152, s. 28-31.
} 
i jednego brakowało. Na koniec wykazu zanotowano, że wcześniej jedna z plebanii i budynek gospodarczy zostały wyremontowane. Zdecydowanie wartościowszych danych dostarcza Wykaz o stanie zabudowań plebanalnych i ekonomicznych za rok $1850^{65}$. Według niego w Klątwach była drewniana plebania o wymiarach 23 na 13 łokci i składała się z trzech pokoi, kuchni i spiżarni. Zabudowania gospodarcze, tj. stodoła (nowo postawiona), obora, stajnia, wozownia i szopa były wykonane z chrustu. W przypadku plebanii, stodoły, wozowni i szopy zawarta jest adnotacja, że są w dobrym stanie, natomiast pozostałe budynki wymagały remontu. W Mikulinie natomiast znajdowała się potrzebująca naprawy plebania o wymiarach 10 na 7 łokci i w dobrym stanie szopa. Z podobnego wykazu, lecz o pięć lat późniejszego, wynika, że ilość budynków w Klątwach pozostała na tym samym poziomie z tym, że wszystkie określono jako „w dobrym stanie”, natomiast w Mikulinie została tylko w bardzo złym stanie plebania, w przypadku której napisano, że „potrzeba nowej”66. Kolejnych informacji o zabudowaniach plebańskich dostarczają cztery wykazy z 1856 roku $^{67}$. Zawarte w nich dane wzajemnie się uzupełniają i w zdecydowanej większości potwierdzają dane z roku 1850. Jedynie w przypadku obydwu plebanii pojawia się wzmianka, że potrzebują naprawy. Dwa o rok późniejsze przekazy, tj. Wykaz szczegótowy za rok 1857 z czynności dotyczacych zarzadu grecko-unickich cerkwi i Wykaz zabudowań plebanalnych, ekonomicznych $i$ stug kościelnych $w$ parafiach dekanatu tyszowieckiego mieszczacych się $w 1857$ roku, zawierają dwa rodzaje danych ${ }^{68}$. W pierwszym z nich podane są ilości budynków i określony ich stan, tj. 2 budynki mieszkalne, w tym jeden w dobrym stanie, a drugiego brakowało; w przypadku zabudowań gospodarczych 5 było w dobrym stanie i 2 brakowało. Informacje powyższe pozwala częściowo zweryfikować drugi przekaz: wymienia 2 plebanie (w Klątwach i Mikulinie), obydwie drewniane pokryte słomą i ,zabudowania ekonomiczne chruściane” w siedzibie parafii. Poza proboszczówką w Mikulinie, której stan określono jako nie najlepszy, pozostałe zakwalifikowane jako „w dobrym stanie”. Jak pokazują późniejsze zapisy źródłowe, określenie stanu plebanii w Mikulinie jako „w nie najlepszym stanie” było zbyt optymistyczne, skoro budynku tego podczas spisu z 1858 roku już nie było, ponieważ się zawalił. W przypadku pozostałych budowli ich ilość i stan techniczny

\footnotetext{
$65 \quad$ Ibidem, sygn. 154. s. 211.

66 Ibidem, sygn. 155, k. 73.

67 Ibidem, sygn. 155, k. 220; sygn. 156, k. 214; sygn. 157, k. 216, k. 231.

$68 \quad$ Ibidem, sygn. 156, k. 469; sygn. 158, k. 126.
} 
nie zmienił się co najmniej do $1865 \mathrm{roku}^{69}$. W wykazie sporządzonym na siedem lat przed likwidacją unii zanotowano, że w parafii był dom drewniany z 2 komnatami i kuchnią dla swiaszczennika, z zaznaczeniem, że był „szczupły” i trzeba wystawić nowy. Ostatnich danych o proboszczówce i budynkach gospodarskich, przed likwidacją parafii unickiej w Klątwach, dostarcza wykaz z 1870 roku $^{70}$. Według niego plebania była drewnianym budynkiem z 3 izbami, długości 9 i szerokości 4 sążni. W przypadku budynków gospodarczych wiadomo tylko, że było ich 9 . Wzmiankowano także, że na remont budynków paroch nie posiada żadnych funduszy, co może sugerować, że ich stan techniczny nie był zbyt dobry.

\section{Duchowieństwo parafii}

W badanym okresie dla parafii w Klątwach ustalono nazwiska 13 duchownych. Niestety, dane dotyczące tych księży są niepełne i zupełnie przypadkowe.

Tabela 3. Duchowni cerkwi w Klątwach

\begin{tabular}{|c|c|c|c|}
\hline Lp. & Imię i nazwisko & Stanowisko & $\begin{array}{l}\text { Wystąpienia } \\
\text { w źródłach }\end{array}$ \\
\hline 1 & Hryć & paroch & 1616 \\
\hline 2 & Bazyli Giliński & paroch & $12.12 .1688,5.06 .1697$ \\
\hline 3 & Atanazy & paroch & po 5.06.1697 \\
\hline 4 & Hrehory Leszczyński & paroch & $1731,3.05 .1732$ \\
\hline 5 & Piotr Leszczyński & wikary & 1760 \\
\hline 6 & Symeon (Szymon) Unifantowicz & paroch & $\begin{array}{l}\text { od 11.05.1762, } \\
12.01 .1799\end{array}$ \\
\hline 7 & Jan Borysiewicz & administrator & $31.01 .1811 ; 16.07 .1811$ \\
\hline 8 & Szymon Unifantowicz & paroch & $1815, \dagger 10.06 .1826$ \\
\hline \multirow[t]{2}{*}{9} & \multirow[t]{2}{*}{ Antoni Unifantowicz } & administrator & po 10.06 .1826 \\
\hline & & paroch & $\begin{array}{l}\text { przed 10.09.1826, } \\
\dagger 10.09 .1826\end{array}$ \\
\hline 10 & Jerzy Malczyński & administrator & 1826 \\
\hline 11 & Ignacy Malczyński & administrator & od 31.12 .1827 do1829 r. \\
\hline 12 & Michał Laurysiewicz & administrator & od 30.03 .1828 do $1832 \mathrm{r}$. \\
\hline
\end{tabular}

69 Ibidem, sygn. 159, k. 79v.; sygn. 160, k. 331; sygn. 161, k. 176v, 499.

70 Ibidem, sygn. 166, k. 359v-360. 


\begin{tabular}{|l|l|l|l|}
\hline Lp. & \multicolumn{1}{|c|}{ Imię i nazwisko } & Stanowisko & \multicolumn{1}{c|}{$\begin{array}{c}\text { Wystąpienia } \\
\text { w źródłach }\end{array}$} \\
\hline 13 & Józef Sajkiewicz & administrator & $\begin{array}{l}\text { od } 30.06 .1832 \mathrm{do} \\
11.10 .1838\end{array}$ \\
\cline { 3 - 4 } & & paroch & $\begin{array}{l}\text { od 29.09. 1838, } \\
\text { zrezygnował } \\
31.01 / 12.02 .1858 \mathrm{r} .\end{array}$ \\
\hline \multirow{2}{*}{13} & Wiktor Sajkiewicz & kooperator & od 18/30.11.1855 \\
\cline { 3 - 4 } & & administrator & od 12.02 .1858 \\
\cline { 3 - 5 } & & paroch & od 4.05.1863 \\
\hline
\end{tabular}

Źródła: AGAD, ASK, Dz. XVIII, sygn. 47, k. 51; APL, AmT, sygn. 3, s. 320; sygn. 4, s. 243; sygn. 38, s.481,483; APL, ChKGK, sygn. 1, s. 129; sygn. 2, s. 96; sygn. 44 , s. 131 ; sygn. 100 , k. 54 ; sygn. 110 , s. 404-405; sygn. 146 , s. 158, 177; sygn. 147 , s. $13,19,85,127.152,245,273,323$; sygn. 148 , s. $26,30,69,104,153,296$; sygn. 150 , s. $21,81,85,134,171,173,263,275,377$; sygn. 151 , s. 29, 205; sygn. 152 , s. 26 -27; sygn. 154 , s. 66,91 , 495; sygn. 163 , k. 173 , 358; sygn. 169 , k. $595 \mathrm{v}-$ 596 ; sygn. 636 , s. 99 ; sygn. 643 , s. 97-98; sygn. 645 , s. 1; sygn. 646. s. 27-28.

W latach siedemdziesiątych XIX wieku proboszcz w Klątwach miał do pomосу причетника czyli osobę posługującą do mszy, która nie była kapłanem ani diakonem (czyli osobą posiadającą święcenia), mogła natomiast czytać Pismo Święte, śpiewać, sprzątać cerkiew, itd. Na stanowisko to od 1871 roku został mianowany dwudziestosiedmioletni Mikołaj Kozłowski ${ }^{71}$.

\section{Wierni}

Pierwszych danych o unitach w parafii Klątwy dostarczają dopiero XVIII-wieczne protokoły wizytacji tej parafii. Niestety, w pierwszym z nich z 1731 roku tylko wspomniano, że wspólnotę wiernych stanowili unici zamieszkujący wieś Klątwy ${ }^{72}$. Kolejne 3 protokoły wizytacji, z lat 1760, 1775 i 1780 także nie podają dokładnej liczby wiernych i ograniczają się jedynie do przedstawienia liczby „,sposobnych do spowiedzi" "Mając tego typu dane i chcąc oszacować ogólną liczbę wiernych, należy (za Cezarym Kuklo) do uprawnionych do przyjmowania komunii św. doliczyć co najmniej $25 \%$ wiernych, które stanowiły dzieci młodsze ${ }^{74}$. W związku z powyższym widząc, że w latach 1760 , 1775 i 1780 sakramenty przyjmowało kolejno 70, 80 i 100 wiernych,

\footnotetext{
$71 \quad$ Ibidem, sygn. 170, k. 7; sygn. 168, k. 465-466.

72 Ibidem, sygn. 100, k. 54.

$73 \quad$ Ibidem, sygn. 110, s. 404; sygn. 122, k. 253; sygn. 127, k. 181v. 
to po dodaniu do tych wartości jeszcze $25 \%$,niekomunikujących”, to szacunkowa liczba parafian będzie wynosiła w kolejnych latach 87, 100 i 125 osób.

Tabela 4. Liczba wiernych parafii unickiej w Klątwach w latach 1760-1875

\begin{tabular}{|c|c|c|c|c|c|c|c|c|c|c|c|c|c|c|}
\hline \multicolumn{2}{|l|}{ Lata } & 1760 & 1775 & 1780 & 1811 & 1815 & 1816 & 1818 & 1819 & 1820 & 1828 & 1829 & 1832 & 1836 \\
\hline \multirow{2}{*}{$\begin{array}{l}\text { Liczba } \\
\text { wiernych }\end{array}$} & ogółem & 87 & 100 & 125 & 452 & 370 & 452 & 471 & 471 & 471 & 487 & 584 & 486 & 283 \\
\hline & $\begin{array}{l}\text { do } \\
\text { spowiedzi }\end{array}$ & 70 & 80 & 100 & 327 & - & 327 & - & - & - & - & - & - & - \\
\hline \multicolumn{2}{|l|}{ Lata } & 1837 & 1838 & 1839 & 1840 & 1841 & 1846 & 1849 & 1850 & 1851 & 1852 & 1853 & 1854 & 1855 \\
\hline \multirow{2}{*}{$\begin{array}{l}\text { Liczba } \\
\text { wiernych }\end{array}$} & ogółem & 390 & 397 & 395 & 400 & 397 & 521 & 525 & 522 & 525 & 518 & 517 & 521 & 485 \\
\hline & $\begin{array}{l}\text { do } \\
\text { spowiedzi }\end{array}$ & - & - & - & - & - & - & - & - & - & - & - & - & \\
\hline \multicolumn{2}{|l|}{ Lata } & 1856 & 1857 & 1858 & 1859 & 1860 & 1862 & 1863 & 1864 & 1868 & 1870 & 1872 & 1875 & \\
\hline \multirow{2}{*}{$\begin{array}{l}\text { Liczba } \\
\text { wiernych }\end{array}$} & ogółem & 480 & 477 & 487 & 492 & 496 & 500 & 500 & 510 & 526 & 548 & 552 & 555 & \\
\hline & $\begin{array}{l}\text { do } \\
\text { spowiedzi }\end{array}$ & 365 & 361 & 366 & 365 & 389 & - & - & - & 308 & 512 & - & 314 & \\
\hline
\end{tabular}

Źródło: APL, ChKGK, sygn. 110, s. 404; sygn. 122, k. 253; sygn. 127, k. 181v; sygn. 146, s. 177 ; sygn. 147 , s. 40,134 ;sygn. 148 , s. 188,249 ; sygn. 149 , s. 233 ; sygn. 150 , s. 176,352 ; sygn. 151 , s. $81,164,340,540$; sygn. 152 , s. $26-27$; sygn. 154 , s. 112 , $254,470,745$; sygn. 155 , k. 118, 219, 345; sygn. 156, k. 133, 284, 579, 693; sygn. 157, k. 229; sygn. 158, k. 130; sygn. 159, k. 92; sygn. 160, k. 40; sygn. 163, k. $91,329,431$; sygn.165, k. 61 ; sygn. 166 , k. 34v-35, 326v-327; sygn. 169, k. 144, $595 \mathrm{v}-596$; sygn. 170, k. 503v-504; sygn. 230, k. 2v, $24 \mathrm{v}-25$.

Dane dotyczące liczby ludności w XIX wieku pochodzą ze spisów statystycznych i raportów periodycznych dziekanów. Informacje tam zawarte występują w dwóch formach. Pierwszy typ danych zawiera tylko ogólną liczbę wiernych, natomiast drugi określa także liczbę sposobnych do spowiedzi. Niestety, tak dokładne dane występują tylko w dziesięciu przypadkach. Na ich podstawie obliczono, że osoby mogące przystępować do sakramentów stanowiły od $56 \%$ do $78 \%$, a średnia dla tych czterech lat kształtowała się na poziomie około 71,3\% ogółu wiernych ${ }^{75}$. Można więc domniemywać, że dla lat, dla których nie ma danych dotyczących ilości komunikujących, ich liczba wynosiła około $70 \%$ wszystkich wiernych. Należy także zaznaczyć, że dla lat 1868 i 1875 wskaźnik komunikujących do ogółu wiernych jest niższy

$75 \quad$ Należy zaznaczyć, że podobny współczynnik dla parafii Łaszczów 62\%, parafii Pieniany wyniósł $63,55 \%$, parafii Grodysławice 65,35\%, parafii w Łosińcu 72 , $6 \%$, a parafii Żerniki 74,4\%. 
Historia Kościoła

o ponad $10 \%$ niż w pozostałych latach. Należy zatem sądzić, że w tych latach urodziło się więcej dzieci, co odbiło się na strukturze wiernych. Większa liczba dzieci oznaczała, że ich udział w ogólnej liczbie parafian wzrastał, a tym samym odsetek dorosłych - mogących przystąpić do spowiedzi - zmniejszał się.

Jednym z najistotniejszych aspektów charakterystyki społeczności parafialnej pozostaje zagadnienie kształtowania się wierzeń i poziomu religijnego uświadomienia. Niestety, w przypadku parafii Klątwy występuje niedostatek źródeł. Pierwsza tego typu (pośrednia) informacja pochodzi z 1760 roku i pozwala wnioskować, że niektórzy wierni nie znali podstaw wiary, skoro wizytator nakazal parochowi: „nieumiejącym przedniejszych artykułów wiary i katechizmu osobom ślubu nie dawać"76. Dzięki wpisowi w aktach miasta Tyszowiec z 23 października 1769 roku wiadomo, że w Klątwach funkcjonowało bractwo cerkiewne. Sprawa dotyczyła nieoddania długu przez zmarłego Jakima Bojczuka bractwu cerkiewnemu. Z dalszej części zapisu wydaje się, że dług ten był zabezpieczony na budynku stojącym na wale za cerkwią miejską, który być może następnie przekazał swojej siostrze Annie Jurkiewiczowej. Zapewne śmierć dłużnika spowodowała, że bracia cerkiewni zaczęli dochodzić swoich praw u starosty. W związku z tym zapewne ekonom starostwa tyszowieckiego, Wojciech Brzozowski, nakazał, żeby na poczet długu był zabrany wspomniany wyżej dom, którego wartość ławnicy tyszowieccy Mateusz Palijowski i Bazyli Starkiewicz oszacowali na $55 \mathrm{zf}^{77}$. Co prawda, nie wiadomo, czym zajmowało się bractwo w Klątwach, można być pewnym, że podobnie jak w innych parafiach, jego członkowie trudnili się dostarczaniem świec na ołtarze, dbali o rozwój kultu, pogłębianie życia chrześcijańskiego swoich członków oraz prowadzili określoną działalność religijną bądź społeczną ${ }^{78}$. Kolejnych danych o religijności unitów parafii klątwowieckiej dostarcza Wykaz obejmujacy wiadomości, co do wykonania obowiązków religijnych

76 Ibidem, sygn. 110, s. 404.

77 APL, AmT, sygn. 7, s. 159.

78 Szerzej na temat bractw zob. W. Kołbuk, Ustawy i statuty unickich bractw cerkiewnych, [w:] R. Łużny (red.), Unia brzeska. Geneza, dzieje i konsekwencje w kulturze narodów słowiańskich, Kraków 1994, s. 329-336; D. Olszewski, Kultura $i$ życie religijne społeczeństwa polskiego $w$ XIX wieku, Lublin 2014, s. 165-176; J. Isajewicz, Bractwa cerkiewne w diecezjach przemyskich obrzadku wschodniego w XVI-XVIII wieku, [w:] S. Stępień (red.), Polska - Ukraina 1000 lat sąsiedztwa, t. 3, Przemyśl 1996, s. 63-74; A. Mironowicz, Bractwa cerkiewne w Rzeczypospolitej, Białystok 2003; K. Kuźmak, Bractwa Matki Boskiej Wspomożycielki Chrześcijan na ziemiach polskich w XVIII stuleciu. Studium do dziejów kultu maryjnego i wspólnot chrześcijańskich w dawnej Polsce, Rzym 1973. 
i w ogóle stanu moralności parafian dekanatu tyszowieckiego $w 1856$ $r^{79} \mathrm{Z}$ analizy tego źródła wynika, że parafianie sumiennie wypełniali swoje religijne powinności, skoro sporządzający wykaz ks. Julian Stabniewicz, dziekan tyszowiecki, napisał: „Lud gorliwy, wszystkie obowiązki religijne wypełnia”. Podobnie sytuacja przedstawiała się w roku następnym, o czym świadczy adnotacja w wykazie: „Parafianie obowiązki religijne wypełniają należycie" 80 . Zgoła inny obraz przedstawiają wykazy za lata 1858 i $1860^{81}$. Sporządzający je ks. Jan Ulanicki, dziekan tyszowiecki, w obydwu przypadkach zanotował:

W dekanacie dostrzegać się daje gwałcenie niedziel i świąt, w które lud parafialny w porze letniej zbiorem siana i zboża zwykł się zajmować. Środki moralne przebierane ze strony duchowieństwa nie są dobre, od tego go [parocha] odprowadziłem. Koniecznie potrzebne są inne środki, które ze strony władz policyjnych skuteczniej mogły być użyte.

Niestety, przebadane źródła nie pozwalają na jasne określenie, dlaczego tak diametralnie różne opinie o parafianach tyszowieckich wydali obaj dziekani. Jedyne, co można domniemywać w tej sprawie, to różnice w ich osobowości i w indywidualnym poglądzie na sprawę „religijności” swoich owieczek.

\section{Zakończenie}

Parafia pw. Kuźmy i Damiana w Klątwach prawie do końca XVIII stulecia była jednowioskową wspólnotą wiernych. Po I rozbiorze Polski parafia ta znalazły się w monarchii habsburskiej. W wyniku przeprowadzonej tam tzw. reformy józefińskiej, jako cerkiew filialna została do niej włączona parafia pw. Wniebowstąpienia Pańskiego w Mikulinie. W takiej organizacji parafia Klątwy przetrwała do 1875 roku, czyli momentu likwidacji unii na terenie byłego Królestwa Polskiego. W pierwszym okresie funkcjonowania w parafii była jedna cerkiew, a po włączeniu parafii w Mikulinie dwie, które były obsługiwane najczęściej przez jednego parocha. Dla badanego okresu ustalono 13 duszpasterzy. Plebania i zabudowania gospodarcze znajdowały się przy obydwu świątyniach. Głównym źródłem utrzymania duchownego były grunty położone przy cerkwiach, dziesięcina od parafian oraz opłaty iura stolae. Określenie liczby wiernych jest szczególnie trudne dla XVIII stulecia, kiedy to wizytatorzy nie badali szczegółowo tego zjawiska, kontentując się jedynie pobieżnymi wyliczeniami. Dla

79 APL, ChKGK, sygn. 157, k. 229.

80 Ibidem, sygn. 158, k. 130.

81 Ibidem, sygn. 160, k. 92; sygn. 161, k. 144. 
opisanego czasu ustalono, że parafia obejmowała swoim zasięgiem od 87 do 555 wiernych.

Słowa klucze: parafia, cerkiew, uposażenie, paroch, unici, utensylia.

Historia Kościoła

\section{Bibliografia:}

\section{Archiwalia}

1. Archiwum Główne Akt Dawnych w Warszawie, zespół:

2. Archiwum Skarbu Koronnego, sygn. 36, 37, 47, 51

3. Archiwum Państwowe w Lublinie, zespół:

4. Chełmski Konsystorz Greckokatolicki, sygn. 1, 2, 44, 100, 110, 122, 127, $139,146,147,148,149,150,151,152,154,155,156,157,158,159,160,161$, $163,165,166,167,168,169,170,230,602,604,643,645,646$

5. Księgi Grodzkie Grabowieckie, sygn. 93, 122, 245

6. Akta miasta Tyszowce, sygn. 3, 4, 7, 38

7. Центральний Державний Історичний Архів України у Львові, zespół:

8. фонд (ф)1, оnuc (on.) 1, cnpaba (cn.) 596, 598,

9. фонд 2, оnuc. 1, cnpaba 203, 215

\section{Źródła drukowane}

1. Matricularum Regni Summaria, t. II, wyd. T. Wierzbowski, Warszawa 1905.

2. Źródta dziejowe, t. XVIII, część I, Polska XVI wieku pod względem geograficzno-statystycznym, t. VII, część I, Ziemie Ruskie. Ruś Czerwona, oprac. A. Jabłonowski, Warszawa 1902.

3. Żereła do istoryi Ukrainy-Rusy, t. VII, oprac. M. Gruszewskij, Lviv 1900.

\section{Opracowania}

1. Bieńkowski L., Diecezja prawosławna, [w:] R. Łukaszyk, L. Bieńkowski, F. Gryglewicz (red.), Encyklopedia katolicka, Lublin 1988, t. 3.

2. Brückner A., Stownik etymologiczny języka polskiego, Warszawa 1970.

3. Ciołko D., Latynizacja Kościoła unickiego w Rzeczypospolitej po synodzie zamojskim, Białystok 2014.

4. Dudziak J., Dziesięcina, [w:] R. Łukaszyk, L. Bieńkowski, E. Gryglewicz (red.), Encyklopedia katolicka, t. IV, Lublin 1985.

5. Frykowski J. A, Niedźwiedź E., Niedźwiedź J., Dzieje miejscowości gminy Tyszowce powiat tomaszowski, Tyszowce - Zamość 2008.

6. Frykowski J., Niegrodowe starostwo tyszowieckie w latach 1519-1768. Studium społeczno-gospodarcze, Tomaszów Lubelski 2009.

7. Frykowski J. A., Parafia unicka $w$ Rachaniach do 1811 roku, „Annales UMCS", vol. LXVII, nr 2 (2012).

8. Frykowski J. A., Parafie prawostawne i unickie $w$ Tyszowcach XVI-XVIII wieku, „Radzyński Rocznik Humanistyczny”, nr 10 (2012).

9. Frykowski J. A., Z dziejów Diecezji Unickiej w Chetmie. Parafia unicka $w$ Łaszczowie do 1863 r., „Rocznik Chełmski”, t. 17 (2013). 
10. Frykowski J. A., Dzieje parafii unickiej w Pienianach, „Radzyński Rocznik Humanistyczny", nr 12 (2014).

11. Gil A., Prawostawna Eparchia Chetmska do 1596 r., Lublin-Chełm, 1999.

12. Gil A., Chetmskie diecezje obrzadku wschodniego. Zagadnienia organizacji terytorialnej w XVII i XVIII wieku, [w:] S. Stępień (red.), Polska-Ukraina. 1000 lat sąsiedztwa, t. 5, Przemyśl 2000.

13. Gil A., Chełmska diecezja unicka 1596-1810. Dzieje i organizacja. Studia $i$ materiaty $z$ dziejów chrześcijaństwa wschodniego w Rzeczpospolitej, Lublin 2005.

14. Gil A., Skoczylas I., Kościoły wschodnie w państwie polsko-litewskim $w$ procesie przemian i adaptacji: metropolia kijowska w latach 1458-1795, Lublin-Lwów 2014.

15. Gloger Z., Geografia historyczna ziem dawnej Polski, Kraków 1903.

16. Gloger Z., Encyklopedia staropolska, t. 2, Warszawa 1985.

17. Ihnatowicz I., Vademecum do badań nad historia XIX i XX wieku, cz. 1, Warszawa 1967.

18. Isajewicz J., Bractwa cerkiewne $w$ diecezjach przemyskich obrzadku wschodniego w XVI-XVIII wieku, [w:] S. Stępień (red.), Polska - Ukraina. 1000 lat sąsiedztwa, t. 3, Przemyśl 1996.

19. Kamler M., Folwark, [w:] A. Mączak (red.), Encyklopedia historii gospodarczej Polski do roku 1945, Warszawa 1981.

20. Karbownik M., Ofiary iura stolae na ziemiach polskich w latach 1285-1918, Lublin 1995.

21. Karbownik H., Opodatkowanie duchowieństwa i dóbr kościelnych na ziemiach polskich w okresie zaborów 1772-1918, Lublin 1998.

22. Kołbuk W., Duchowieństwo unickie w Królestwie Polskim 1835-1875, Lublin 1992.

23. Kołbuk W., Ustawy i statuty unickich bractw cerkiewnych, [w:] R. Łużny (red.), Unia brzeska. Geneza, dzieje i konsekwencje w kulturze narodów słowiańskich, Kraków 1994.

24. Kuklo C., Demografia Rzeczypospolitej przedrozbiorowej, Warszawa 2009.

25. Kuźmak K., Bractwa Matki Boskiej Wspomożycielki Chrześcijan na ziemiach polskich $w$ XVIII stuleciu. Studium do dziejów kultu maryjnego i wspólnot chrześcijańskich w dawnej Polsce, Rzym 1973.

26. Markunas A., Uczitiel T., Popularny stownik sakralizmów polskich i ukraińskich, Poznań 2000.

27. Mazuryk J., Panyszko S., Ostapiuk O., Badania archeologiczne latopisiwego Uhrowieska, „Archiwum Polski Środkowowschodniej”, nr 3 (1998).

28. Mironowicz A., Struktura organizacyjna Kościoła prawosławnego w Polsce $w$ X-XVIII wieku, [w:] L. Adamczuk, A. Mironowicz (red.), Kościót prawosławny $w$ Polsce dawniej $i$ dziś, Warszawa 1993.

29. Mironowicz A., Bractwa cerkiewne w Rzeczypospolitej, Białystok 2003.

30. Narbutt O., Historia i typologia ksiag liturgicznych bizantyńsko-słowiańskich. Zagadnienie identyfikacji wedtug kryterium treściowego, Warszawa 1979 .

31. Olszewski D., Kultura i życie religijne społeczeństwa polskiego $w$ XIX wieku, Lublin 2014. 
32. Osadczy W., Kościót i Cerkiew na wspólnej drodze. Concordia 1863. Z dziejów porozumienia między obrządkiem greckokatolickim a tacińskim $w$ Galicji Wschodniej, Lublin 1999.

33. Pańczuk B., Księgi liturgiczne, [w:] A. Szostek, E. Ziemann, R. Sawa, K. Góźdź, J. Herbut, S. Olczak, R. Popowski (red.), Encyklopedia katolicka, Lublin 2004, t. X.

34. Poppe A., Kościót i państwo na Rusi w XI wieku, Warszawa 1968.

35. Russocki S., Podymne, [w:] A. Mączak (red.), Encyklopedia historii gospodarczej Polski do 1945 r., t. 2, Warszawa 1981.

36. Seniuk B. M., Osiemnastowieczna terminologia z zakresu architektury i sztuki cerkiewnej oraz organizacji Kościoła wschodniego. Materiaty do słownika na podstawie protokołów wizytacyjnych Eparchii Wtodzimierskiej, [w:] S. Stępień (red.), Polska - Ukraina. 1000 lat sąsiedztwa, t. 5, Przemyśl 2000.

37. Smykowska E., Liturgia prawostawna. Mały stownik, Warszawa 2004.

38. Szymański J., Nauki pomocnicze historii, Warszawa 2005.

39. Turnau I., Stownik ubiorów. Tkaniny, wyroby pozatkackie, skóry, bron $i$ klejnoty oraz barwy znane $w$ Polsce od średniowiecza do poczatku XIX w., Warszawa 1999.

40. Zajda A., Nazwy staropolskich powinności feudalnych, danin i opłat (do 1600 r.), Warszawa - Kraków 1979.

41. Ziółek E. M., Między tronem a ottarzem. Kościót i państwo $w$ Księstwie Warszawskim, Lublin 2012.

42. Слободян В., Церкви Холмскоі епархї, Львів 2005. 